\title{
CAN A LUXURY BRAND BE SOCIALLY RESPONSIBLE? LUXURY BUSINESS AND CORPORATE SOCIAL RESPONSIBILITY - AREAS OF COEXISTENCE
}

\author{
Wioleta Dryl* (ㅇ http://orcid.org/0000-0002-6434
}

\begin{abstract}
Background. One of the areas of business activity that has become not only a matter of voluntary choice in recent times, but more and more often a necessity is CSR. This area is very little recognised and explored in the context of luxury goods. It is obvious that the prosperity of this market gives its participants great opportunities for actions in the area of CSR. However, it is important to consider and examine whether this behaviour is desirable from the perspective of both consumers and other stakeholders of the brand.
\end{abstract}

Research aims. The purpose of this paper is (1) to identify the areas in which socially responsible actions can have a positive impact on the perception of brand value, as well as those that do not apply, and indeed are contrary to these values, and (2) to assess whether and to what extent CSR activities are desirable in the luxury market, both from the consumers and other stakeholders' perspective.

Methodology. For the full explanation and understanding of this issue, the identification of luxury brand values has been conducted. On this basis, the author of the paper has identified the areas in which the socially responsible actions can have a positive impact on the perception of brand value, as well as those that do not apply, and are contrary to these values. The paper reviews the literature, analyses the scope of research conducted in this area and presents examples of socially responsible luxury brands.

Key findings. The results of the analysis conducted in the paper, indicate that although there are more important values of luxury brand than its social responsibility, there are areas of CSR that are compatible with values of luxury brand and there are stakeholder groups that demand socially responsible behaviour from luxury brands. CSR is considered as both the opportunity and the responsibility of luxury sector. Some trends in ethical/social responsible consumption that already exist in the mass market can and should be transposed into the luxury dimension.

* Faculty of Management, University of Gdańsk, Armii Krajowej 101, 81-824 Sopot, Poland. E-mail: wioleta.dryl@ug.edu.pl 
Keywords: luxury, CSR, corporate social responsibility, luxury brand, ethical behaviour.

JEL Codes: A13, M31, M21

\section{INTRODUCTION}

The luxury market is one of the most controversial sectors, it raises intense discussions and always has as many followers as the opponents. The purchasers of luxury goods are most closely associated with conspicuous consumption, spending money on superfluous products. Managers of luxury brands face a particularly difficult task. On the one hand, they have to satisfy the desires of a very specific and demanding customer, on the other, it is expected from them to maintain the best image of the company and brand in the eyes of other stakeholders.

Marketing of luxury goods is often being called as being paradoxical. The tools used in this market stand in complete contradiction with the assumptions of traditional marketing directed to the mass market. However, one should consider whether all the trends that have entered the mass market, should in principle be rejected by luxury brands? Such an approach actually dominated the luxury sector until recently. New technologies, more and more intensive modern communications, have forced luxury marketers to redefine their approach.

One of the areas of business activity that has become not only a matter of voluntary choice in recent times, but more and more often a necessity is CSR. This area is very little recognised and explored in the context of luxury goods. It is obvious that the prosperity of this market gives its participants great opportunities for actions in the area of CSR. However, it is important to consider and examine whether this behaviour is desirable from the perspective of both consumers and other stakeholders of the brand.

The aim of this paper is to assess whether and to what extent CSR activities are desirable in the luxury market, both from the consumers and other stakeholders' perspective. For a full explanation and understanding of this issue, the identification of luxury brand values, important from the perspective of consumers has been conducted. On this basis, the author of the paper identified the areas in which socially responsible actions can have a positive impact on the perception of 
brand value, as well as those that do not apply, and indeed are contrary to these values.

The paper reviews the literature and analyses the scope of research conducted in this area.

\section{LITERATURE REVIEW AND DEFINITION OF THE KEY CONCEPTS AND RELATIONSHIPS BETWEEN THEM}

\section{Definition of luxury goods}

Defining luxury product is not an easy task and must follow an integrative approach (Wiedmann et al., 2009). "What is luxury to one may just be ordinary to another" (Phau \& Prendergast, 2000, p. 123). This statement perfectly reflects the idiosyncratic nature of luxury, and consequently the lack of unanimity in the way of defining the concept of luxury product.

The major challenge in defining luxury products is that luxury and the related terms are especially vague and their meaning depends a lot on the user's perspective (Kapferer, 2008). The consumers' perception of luxury may differ according to many factors. Heine and Sikora recognise the multidimensional nature of the relativity of luxury. According to the authors, the relativity of the luxurious nature of the product has the regional, time, economic, cultural and situational form (Heine \& Sikora, 2012). Previous studies also indicate that the perception of luxury depends on socio-demographic factors such as age, gender, and ethnic groups (Gardyn, 2002).

Given the abovementioned restrictions, it should be noted that only an interdisciplinary, broad perspective allows to create a definition of luxury product, that will not raise a lively debate. The concept of luxury lies in the scope of interest in such sciences as among others: economy, sociology, psychology, management, and marketing. Table 1 presents the definitions of luxury products created by representatives of various sciences, presenting different approaches to the problem. 
Table 1. Definitions of luxury product from the perspective of different sciences

\begin{tabular}{|c|c|c|}
\hline $\begin{array}{l}\text { Approach to } \\
\text { the concept } \\
\text { of luxury } \\
\text { product }\end{array}$ & $\begin{array}{l}\text { Representative } \\
\text { / author }\end{array}$ & Definition \\
\hline \multirow{4}{*}{$\begin{array}{l}\text { Economic } \\
\text { approach }\end{array}$} & Leibenstein (1950) & $\begin{array}{l}\text { The phenomenon of conspicuous consumption, } \\
\text { manifested by an increase in demand for the goods } \\
\text { with the increase in their prices, and the degree of } \\
\text { desire by other consumers }\end{array}$ \\
\hline & McKinsey (1990) & $\begin{array}{l}\text { The category where prices are appreciably higher } \\
\text { to products presenting comparable tangible } \\
\text { features, where price and quality ratios are the } \\
\text { highest of the market }\end{array}$ \\
\hline & $\begin{array}{l}\text { Nueno \& Quelch } \\
\text { (1998) }\end{array}$ & $\begin{array}{l}\text { Products whose ratio of functionality to price is } \\
\text { low, while the ratio of intangible and situational } \\
\text { utility to price is high }\end{array}$ \\
\hline & Kemp (1998) & $\begin{array}{l}\text { Goods, according to which the income elasticity of } \\
\text { their demand is higher than that of the other goods }\end{array}$ \\
\hline \multirow{2}{*}{$\begin{array}{l}\text { Symbolic } \\
\text { approach }\end{array}$} & Kapferer (1997) & $\begin{array}{l}\text { "Luxury defines beauty; it is art applied to func- } \\
\text { tional items. Like light, luxury is enlightening. (...) } \\
\text { Luxury items provide extra pleasure and flatter all } \\
\text { senses at once..." }\end{array}$ \\
\hline & Roux \& Floch (1996) & $\begin{array}{l}\text { A luxury brand is characterised by a symbolic, } \\
\text { imaginary or social added value, which differenti- } \\
\text { ates it from other brands }\end{array}$ \\
\hline \multirow{4}{*}{$\begin{array}{l}\text { Psychological } \\
\text { approach }\end{array}$} & Kemp (1998) & $\begin{array}{l}\text { The product becomes luxurious when the need to } \\
\text { own it is more a result of desire than the need to } \\
\text { eliminate discomfort }\end{array}$ \\
\hline & $\begin{array}{l}\text { Nia \& Zaichkowsky } \\
(2000)\end{array}$ & $\begin{array}{l}\text { These psychological benefits as prestige or self-im- } \\
\text { age's enhancement are the main factor that distin- } \\
\text { guishes luxury products from non-luxury ones }\end{array}$ \\
\hline & $\begin{array}{l}\text { Kapferer \& Bastien } \\
(2009) \\
\text { Vigneron \& Johnson } \\
(2004)\end{array}$ & $\begin{array}{l}\text { "Those that provide extra pleasure and flatter all } \\
\text { senses at once" }\end{array}$ \\
\hline & $\begin{array}{l}\text { Dubois \& Laurent } \\
\text { (1994) } \\
\text { Sweeney \& Soutar } \\
(2001)\end{array}$ & $\begin{array}{l}\text { The intangible perception of luxury is strongly } \\
\text { correlated with pleasure, happiness and inspiration }\end{array}$ \\
\hline $\begin{array}{l}\text { Marketing } \\
\text { approach }\end{array}$ & $\begin{array}{l}\text { Keller (2009) } \\
\text { Kapferer (1997) }\end{array}$ & $\begin{array}{l}\text { Maintaining premium image, controlling distribu- } \\
\text { tion carefully via a selective channel strategy, and } \\
\text { employing premium pricing strategy with strong } \\
\text { quality cues and few markdowns }\end{array}$ \\
\hline \multirow{2}{*}{$\begin{array}{l}\text { Sociological } \\
\text { approach }\end{array}$} & Cornell (2002) & $\begin{array}{l}\text { "A strong element of human involvement, very } \\
\text { limited supply and the recognition of value by } \\
\text { others are key components" }\end{array}$ \\
\hline & Van der Veen (2003) & $\begin{array}{l}\text { The luxury product is the one everyone wants, but } \\
\text { only a few can have }\end{array}$ \\
\hline
\end{tabular}

Source: own work. 
The broad definition of the luxury product, taking into account the interdisciplinarity of this concept was created by Tynan, Mckechine and Chhuon (2010). They recognise as important, the three dimensions of a luxury product: functionalism, experientialism and symbolic interactionism. On this basis, luxury products have been described as high quality, expensive, superfluous products and services that are rare, exclusive, original and prestigious and offer consumers specific experiences related to high levels of symbolic and emotional / hedonistic values (Tynan et al., 2010).

A broad perspective, strongly considering the marketing aspect of the essence of luxury, is presented by the definition created by Dubois, Laurent and Czellar (2001). The definition is presented in Figure 1.

In order to avoid discrepancies in the understanding of the concept of a luxury product, for the purpose of this article, luxury goods

Excellent quality

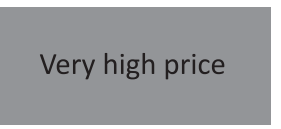

Scarcity and uniqueness

Aesthetics and polysensuality

Ancestral heritage and personal history

\section{Superflouousness}

The first notion is that of perceived excellent quality. The mental association between luxury and quality is so strong that for some respondents, the two words are almost synonymous

The second notion spontaneously associated with luxury, and almost as salient as the previous one is that of high price. Such a perception is established either on the basis of the absolute value of the price, or more frequently, by comparison with non-luxury alternatives

The third concept associated with luxury is that of scarcity. Scarcity is closely associated with the perceived excellent quality and high price associated with luxury goods

The fourth aspect of luxury involves a strong aesthetic appeal. And, according to many consumers, it should be the case. At the extreme, luxury products become pieces of art which have to be recognized as such

The fifth notion associated with luxury is its anchoring in the past. In consumers' mind, to be luxurious, products and services must have a long history and treir elaboration processes as well as consumption ahould respect tradition

Finally, the concept of luxury implies some perceived superfluousness or uselessness. Luxury products are not left to be necessary for survival. It is in this sense that consumers as well as researchers oppose luxuries and necessities

Figure 1. The Definition of Luxury Products by Dubois, Laurent, and Czellar (2001)

Source: Dubois et al., 2001, p. 8. 
are defined as follows (Dryl \& Gil, 2016): high-quality, expensive goods, which are rare, exclusive, original, and prestigious (Tynan et al., 2010), for which demand is growing through increasing their prices (Leibenstein, 1950) and the level of desire by other consumers (Leibenstein, 1950), which are purchased in order to achieve a high social status (Bagwell \& Bernheim, 1996), not influenced by need, but desire, not in order to eliminate discomfort, but in order to provide pleasure (Berry, 1994).

\section{Luxury value perception}

The value of luxury is considered in literature in many respects. Vigneron and Johnson emphasise the physical and psychological values of luxury (1999). The authors have indicated in this regard 5 core values that create the luxury value of the product, namely (Vigneron \& Jonson, 1999):

1) Perceived conspicuousness - related to the effect of the reference groups in the process of consumption. Luxury goods help give their owners the opportunity to be recognised and to acquire a specific identity in the reference group. Luxury goods are a sign of social and symbolic status.

2) Perceived uniqueness - shapes the personal and social identity of the consumer. Limited production of goods causes increase in demand. The uniqueness of the product becomes stronger due to the limited production of handmade products, original design and high price.

3) Perceived quality - luxury products provide a higher quality level in comparison to non - luxury ones. The quality is an important source of satisfaction of luxury goods' consumers and a positive image of the brand.

4) Perceived hedonism - luxury consumption provides emotional experience and values experiences of pleasure, happiness, aesthetics, and fun.

5) Perceived social value/ego - on the one hand, luxury goods consumption let consumers associate with certain prestigious groups, on the other hand, differentiate from non - prestigious reference groups.

It should be noted that, this way of considering luxury value perception is at the same time very broad as well as detailed. As mentioned 
above, the luxury value perception is considered in the literature in many respects. Some interesting approaches to this phenomenon are presented in table 2 .

Table 2. Drivers of luxury value perception

\begin{tabular}{|l|l|}
\hline \multicolumn{1}{|c|}{ Authors } & \multicolumn{1}{c|}{ Luxury value perception } \\
\hline $\begin{array}{l}\text { Bourdieu (1984), } \\
\text { Wiedmann et al. } \\
\text { (2009), Vigneron \& } \\
\text { Johnson (2004) }\end{array}$ & $\begin{array}{l}\text { Social value (i.e. conspicuous value, prestige value), functional } \\
\text { value (i.e. usability value, quality value, uniqueness value, indi- } \\
\text { vidual value (i.e. self-identity value, hedonic value, materialistic } \\
\text { value), financial value (price value) }\end{array}$ \\
\hline Dubois et al. (2001) & $\begin{array}{l}\text { Outstanding quality, excessive price, personal story from the } \\
\text { past, rarity and uniqueness, aesthetics and beauty, uselessness }\end{array}$ \\
\hline Woodall (2003) & Exchange value, intrinsic value, use value, utilitarian value \\
\hline $\begin{array}{l}\text { Vigneron \& Johnson } \\
(2004)\end{array}$ & $\begin{array}{l}\text { Personal perceptions (perceived hedonic value, perceived extend- } \\
\text { ed self), non-personal perceptions (perceived conspicuousness, } \\
\text { perceived uniqueness, perceived quality) }\end{array}$ \\
\hline Ruiz et al. (2007) & \begin{tabular}{l} 
Quality, price value \\
\hline $\begin{array}{l}\text { Smith \& Colgate } \\
\text { (2007) }\end{array}$
\end{tabular}$\quad \begin{array}{l}\text { Symbolic/expressive value, experiential/hedonic value, } \\
\text { utilitarian/functional value, cost/sacrifice value }\end{array}$ \\
\hline $\begin{array}{l}\text { Wiedmann et al. } \\
(2009)\end{array}$ & $\begin{array}{l}\text { Financial value (price value), functional value (usability value, } \\
\text { quality value, uniqueness value), individual value (self-identify } \\
\text { value, hedonic value, materialistic value), social value (conspicu- } \\
\text { ousness value, prestige value) }\end{array}$ \\
\hline Berthon et al. (2009) & $\begin{array}{l}\text { Objective value (material), subjective value (individual), collec- } \\
\text { tive value (social) }\end{array}$ \\
\hline Tynan et al. (2010) & $\begin{array}{l}\text { Symbolic/expressive value (self-directed, other-directed), experi- } \\
\text { ential/hedonic value, utilitarian/functional value, cost/sacrifice } \\
\text { value }\end{array}$ \\
\hline Wang et al. (2010) & $\begin{array}{l}\text { Interpersonal - orientated perceptions (conspicuousness value, } \\
\text { quality value), personal orientated perceptions (hedonism, ex- } \\
\text { tended-self) }\end{array}$ \\
\hline
\end{tabular}

Source: own work.

In accordance with the considerations outlined in the previous section of the article, rarity and uniqueness are the essential features that define a luxury character of the product. Research on the perception of luxury confirms the validity of this approach. The uniqueness of luxury goods lies in their inaccessibility for the average non-prestige consumers. There are many barriers that can be built to achieve an appropriate level of inaccessibility, such as high price, limited distribution or limited natural resources of the product. When it comes to uniqueness, the authors suggest that the aesthetics, design, and 
handmade production may be the sources of the value. These values are also pointed out by Vigneron and Johnson (2004).

Taking into account the considerations presented in the literature on luxury goods and the results of research in this area, it can be seen that the most popular model of perceived value of luxury is the one created by Wiedmann et al. (Figure 2).

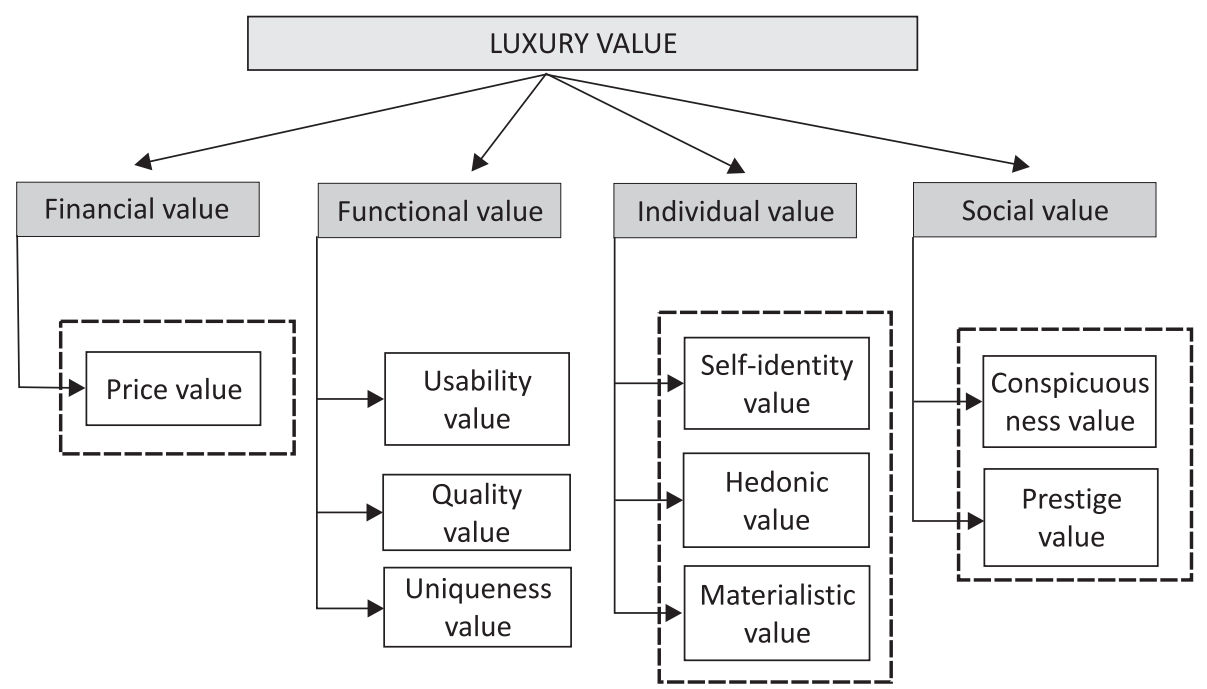

Figure 2. Luxury value perception

Source: based on: Wiedmann et al., 2009, p. 7 .

\section{CSR definition}

Corporations are nowadays encouraged to behave socially responsibly (Engle, 2006). The main problem is that, for some organisations the meaning of CSR is not clear, and for the others the social responsibility is not important enough to pay an appropriate attention to this issue. According to Bowen, who is called the father of corporate social responsibility, CSR should be considered as "the obligations of businessmen to pursue those policies, to make those decisions, or to follow those lines of action which are desirable in terms of the objectives and values of our society" (Bowen, 1953, p. 6). The cited definition was created in the early 1950s. Nowadays, the meaning of CSR has transformed from philanthropy to regular practices (Rojek-Nowosielska, 
2015). Modern companies are under intense pressure on compliance with regulations on environmental protection, transparency, and the necessity of the introduction of CSR as a strategy to survive and be more efficient (Glan, 2006).

Corporate Social Responsibility is both in the interest of business, science, international political organisations, as well as broad stakeholders: consumers, organisations protecting the environment and human rights, and so on (Raczkowski et al., 2016). According to the results of the study conducted in 2006, there were 37 definitions of CSR in the literature (Dahlsrud, 2005). Despite the multitude of definitions of CSR, it is possible to indicate the basic characteristics and scope of activities in this area. Worth the attention is certainly the definition according to which:

The social responsibility of business encompasses the economic, legal, ethical, and discretionary (later referred to as philanthropic) expectations that society has of organizations at a given point in time (Carroll, 1999, p. 269).

It presents four basic dimensions of CSR, which can be interpreted as the expectations placed on the corporation by corporate stakeholders and society as a whole (Caroll \& Shabana, 2016).

1) Economic responsibility - "to produce goods and services that society desires and to sell them at a profit" (Carroll, 1999, p. 269).

2) Legal responsibilities - "The legal responsibilities of business refer to the positive and negative obligations put on businesses by the laws and regulations of the society where it operates" (Caroll \& Shabana, 2016, p. 91). While meeting these legal responsibilities, important expectations of business include: - performing in a manner consistent with expectations of government and law,

- complying with various federal, state, and local regulations,

- conducting themselves as law-abiding corporate citizens,

- fulfilling all their legal obligations to societal stakeholders,

- providing goods and services that at least meet minimal legal requirements (Caroll \& Shabana, 2016).

3) Ethical responsibilities - Taking on ethical responsibilities implies that organisations will embrace those activities, 
norms, standards, and practices that even though they are not codified into law, are expected nonetheless. While meeting these ethical responsibilities, important expectations of business include:

- performing in a manner consistent with the expectations of societal mores and ethical norms,

- recognising and respecting new or evolving ethical/moral norms adopted by society,

- preventing ethical norms from being compromised in order to achieve business goals,

- being good corporate citizens by doing what is expected morally or ethically,

- recognising that business integrity and ethical behaviour go beyond mere compliance with laws and regulations (Carroll, 1991).

4) Strategic philanthropy, defined as "the process by which contributions are targeted to serve direct business interests while also servicing beneficiary organizations" (Tokarski, 1999, p. 34), helps companies to gain a competitive advantage and, in turn, boosts its bottom line (Seifert et al., 2003).

The above-mentioned responsibilities are the levels of pyramid, referring to Maslow's Pyramid. Hence the name of the concept: Carroll's Pyramid of CSR, to which refer, among others Wartick and Cochran (1985).

It is also important to emphasise that trust is increasingly important in building positive relationships with stakeholders. This factor is also determined by CSR activities. Trust makes consumers willing to recommend products, which is a testament to their high satisfaction and even loyalty to the brand (Dryl, 2014).

A feature of CSR, which most often appears in the definitions presented in the literature, is the voluntary nature. However, one should consider whether in today's highly competitive market, a company can succeed if it does not operate in accordance with CSR guidelines. On the one hand, segments of ethical and ecological consumers, and prosumers by their expectations, pressures and purchasing decisions are forcing on companies the pro-social activities. On the other hand, companies through their offers enriched by consumer preferences (products, packaging, social campaigns, educational activities) shape the social attitudes of consumers and their behaviour. It can therefore 
be said that socially sensitive consumers influence the growth of socially responsible companies and vice versa - socially responsible companies influence pro-social behaviour of consumers (Czubała, 2011).

\section{METHOD}

The purpose of this paper is (1) to identify the areas in which the socially responsible actions can have a positive impact on the perception of brand value, as well as those that do not apply, and indeed are contrary to these values, and (2) to assess whether and to what extent CSR activities are desirable in the luxury market, both from the consumers and other stakeholders' perspective. The analysis of literature in the field of luxury products and the dimensions of their value as well as corporate social responsibility was carried out for the need to implement aim number 1 . The author reviewed the categorisation of the dimensions of the value of the luxury brand, and also presented the concept by Wiedmann et al. (2009), which in the further part of the article is the basis for considering the compliance of the values of luxury brand with the CSR concept. On the basis of the literature analysis, the areas and objectives of the concept of corporate social responsibility were also indicated.

To achieve the aim number 2 , the author analysed secondary sources, namely the results of research carried out so far by such authors as Avies et al. Social responsibility of luxury is still a poorly investigated concept. The results of the research of Avies et al. mainly concern consumers' expectations regarding the ethical sphere of social responsibility of luxury brands. Research on responsible luxury has not been undertaken in Poland so far. The KPMG research company conducts an annual research on the market and behaviour of consumers of luxury goods in Poland. One of the areas of the study is the relevance of particular characteristics of luxury goods from the consumers' point of view. The participants of the study are: affluent people (with a gross monthly income between PLN 7-10 thousand), very affluent people (with a gross monthly income between PLN 10-20 thousand), and rich people (with a gross monthly income in excess of PLN 20 thousand). The author of the article has analysed the results of KPMG research (edition 2016) in terms of the expectations of Polish consumers of luxury goods related to corporate social responsibility. 
To sum up, for the purpose of this article, the author has used such research methods as literature analysis and analysis of secondary sources: studies carried out by Davies et al. (2012) and KPMG.

\section{RESULTS AND DISCUSSION}

\section{Perceived value of luxury and Corporate Social Responsibility - contradiction or common voice? - literature review}

"The notion of 'responsible luxury' may appear as a contradiction in terms" (Janssen et al., 2014, p. 46). Responsible luxury is certainly a controversial statement, but what is important is becoming an increasingly popular area of both theoretical consideration and research. Researchers of the phenomenon recognise the growing need to analyse this area and at the same time to make the luxury goods companies aware of the importance of CSR in their activities. According to Bendell and Kleanthous (2007), luxury brands "have both the opportunity and the responsibility to promote sustainable consumption". Trends in ethical consumption that already exist in the mass market will naturally be transposed into the luxury dimension.

\section{Ethical dimension}

The ethical side of the luxury business is particularly prominent in the literature. Previous studies - although very few, prove that CSR is not an essential factor determining consumers' choices on the luxury market. According to a study by Davies et al. (2012) ethical responsibility of luxury brands is of marginal importance for their consumers. Interestingly, on the one hand, the authors suggest that we live in an "ethic era", but on the other hand, they indicate the results of research in which even in the mass market "for most product categories, ethical products account for less than 1\% of the total market share" (The Co-operative Bank, 2009, as cited in: Davies et al., 2012). The authors suggest that "this ethics era is more limited in application than the literature sometimes suggests".

The assumption of ethical consumption is that consumers are concerned with the effects that a purchasing choice has, not only on 
themselves, but also on the external world around them (Harrison et al., 2005). According to the results of the previous studies, the trend towards ethical consumption, is the strongest for food related products, cosmetics, and apparel (Auger et al., 2003; McGoldrick \& Freestone, 2008). These categories have the largest share in the ethical products market (The Co-operative Bank, 2009, as cited in: Davies et al., 2012). The literature also identifies ethical products, primarily eco-labels (Anderson \& Hansen, 2004; Bjørner et al., 2004) or fair-trade brands (Pelsmacker et al., 2005; Loureiro \& Lotade, 2005). Davies et al. point to the need to extend the research into wider product categories, such as luxury goods (Davies et al., 2012).

According to Barnier et al. (2006), defining the luxury goods and their potential for growth in ethical consumption, three interrelated perspectives must be considered, such as:

- the economic view,

- the psychological view,

- the marketing view.

To accurately determine the potential of luxury goods in the context of their ethical dimension, one should refer to dimensions of perceived luxury value. The key question to answer is: whether the values of luxury products, considered relevant to their consumers, correspond to the basic principles of ethical/responsible consumption. Taking into account the financial value of luxury, the source of which can be found in the economics approach to the definition of luxury, the first factor to consider is the price. According to the definition of luxury goods, the price-to-functionality and quality ratio of the product is extremely low (Wiedmann et al., 2009). At the same time, it should be noted that the high price is also a result of the marketing strategy of luxury brands. At this point one should consider whether this type of strategy, based on unreasonably high level of price, is ethical?

According to many opponents of luxury brands, consumption of luxury goods involves spending huge amounts on products, by definition useless, while this money could be used to help poorer regions of the world. Taking actions to finance the poor communities and, of course, properly communicating this fact to engaged consumers can break this popular opinion about the luxury sector. Luxury brands support numerous initiatives. It should be emphasised, however, that they focus primarily on sponsoring/supporting activities the image of which is compatible with the personality of the brand. Therefore, 
these are usually events and institutions from the circle of culture, art, sport, science, and medicine/health. Taking into account the fact that the image of many luxury brands is based on their history as well as the history of their creators or the places in the world that are their roots, it has become particularly popular to finance the brand-relevant cultural monuments, works of art, etc. Examples of this type of activities may be brands like Fendi, Bulgari, and Tods, which have donated to Italian architectural icons such as Roman fountains, the Spanish Steps, and the Colosseum, etc. Prada's foundation supports arts, architecture, and "philosophy projects". Omega announced a five-year partnership with a new section of Milan's Leonardo da Vinci Museum of Science and Technology devoted exclusively to space and astronomy.

But these are not the only opportunities for a more legitimate and socially desirable way of spending money by luxury goods manufacturers. Brands can raise awareness while creating value for the company also by giving charity through the sale of dedicated products. For example, brands from The Estee Lauder Group launched a range of "Pink Ribbon Products", which each contribute a proportion of sales to The Breast Cancer Research Foundation. Similar actions are being led by Gucci, handing $10 \%$ of its sales income from the Fifth Avenue Flagship store during a specific period in June 2014, to raise additional support for girls and women around the world.

It should be noted, that such activities can certainly be considered as a mature approach to CSR activities. What is important in the context of the theory is that these actions are part of the principles of Carolls' pyramid - the luxury brands presented above, carry out activities that are both philanthropic and break the ethical controversy surrounding the consumption of luxury goods. The awareness that part of the high price of a luxury product is intended to support the initiatives mentioned above may, to some extent, justify the consumption of luxury goods.

However, this is the point of view of manufacturers of luxury goods. From a consumers' point of view the high price is considered from another perspective. According to the results of numerous studies on the perception of luxury, the high price is a testament to the high quality of the luxury product, and it also constitutes a barrier limiting access to luxury brands to consumers, undesirable from the brands' point of view - the less affluent ones. 
An important aspect of CSR strategy is the identification and evaluation of stakeholder groups. Certainly, customers are an important stakeholder for any business. However, given the controversy surrounding conspicuousness consumption, the society and its expectations are particularly important for the manufacturers of luxury goods. The luxury industry is faced with the challenge of creating the right communication that will justify the high price of the product, not just by the snobbish character of the consumer, but also the social well-being in general.

\section{Individual values}

The next perspective which needs to be considered while aiming to define the luxury goods potential for growth in responsible consumption is psychological view. According to many researchers, mentioned in previous chapter of the paper (Mason, 1992; Vickers \& Renand, 2003; Vigneron \& Johnson, 2004), the psychological view explores the intra and interpersonal context of luxury consumption, around peer and self - perception. According to Nia and Zaichkowsky (2000, p. 487), "psychological benefits as prestige or self-image's enhancement are the main factor that distinguishes luxury products from non-luxury ones".

The psychological approach to the luxury product definition, emphasises also the fact that luxury goods do not fill the basic needs, but they meet the desires (Mortelmans, 2005), they "provide extra pleasure and flatter all senses at once" (Kapferer \& Bastien, 2009, p. 313). This is quite a controversial way of defining luxury products, which is arousing disapproval of the society sensitive to the problem of poverty. The basic dilemma is whether or not the company can base its efforts on satisfying the desires of the "leisure class" and at the same time be socially responsible. This dilemma is recognised not only by luxury companies but also by the researchers of this phenomenon. According to Amatulli et al.:

The growing consumers' sensitivity toward the social and environmental impact of luxury consumption, paired with the fact that many luxury companies are still not used to thinking about themselves as able to deliver dreams while being sustainable, indicates that the whole luxury industry would need a new strategic approach to develop luxury brands, as well as marketing professionals with the right skills to appeal to changing consumers (Amatulli et al., 2017, p. 3). 


\section{Social values}

Taking into consideration the subject of psychological values relevant to the consumer of luxury goods, one cannot ignore the social value of luxury. This is one of the values of a luxury product that is strongly opposed to CSR. The conspicuous consumption and spending money on products and services, to demonstrate the high social class and to cause envy, was already described by Veblen in 1899. This theory has given rise to considering the luxury goods, as products that allow the consumer to stand out from the class of lower social status (Bagwell et al., 1996).

This aspect of consumption of luxury goods has awakened and still raises serious controversies and is widely criticised. Manufacturers of luxury goods have a very difficult task, on the one hand, their consumers expect the luxury brand to distinguish themselves, and to make them feel better than the rest of the society, and on the other hand, the public clearly criticises this kind of attitude. It should be noted that, this is a particularly troublesome aspect of the value of luxury goods for their manufacturers. The social dimension of consumption of luxury goods strongly contradicts the idea of CSR. From both theoretical and practical points of view, it is not justified, and more importantly not possible, to modify the perception of luxury in the context of its social value.

\section{Functional values}

The marketing view, as the last aspect of luxury goods potential in ethical consumption, should be considered in a very wide perspective. According to marketing definitions, a luxury product should be accompanied by premium image, high quality, craftsmanship, limited distribution, high price, and low promotional activity (Chevalier \& Mazzalovo, 2008).

One of the criticised aspects of mass production is the transfer of their production to the Eastern markets, where labour costs are significantly lower than in other parts of the world. This treatment has been heavily criticized for the use of people for working in bad conditions, for very low rates and, above all, for employing children. Until recently, the luxury sector was outside of the circle of criticism in this aspect, as luxury brands boasted their own production of 
goods in countries such as France or Italy - the cradle of luxury. Increasingly, however, democratized luxury also moves its factories to the East, what in the near future will undoubtedly expose the luxury brands to attacks of the stakeholder for whom fair trade is of great importance.

Luxury brands also pride themselves on the highest quality materials used to produce their products. More and more brands insist on ethical and ecological sourcing of raw materials. For example, Hermes invested in Shang Xia, a Chinese premium luxury brand of graceful, contemporary handcrafted products. The usage of Cashmere Felt, Zitan Wood, Eggshell Porcelain, and Bamboo Weaving are some of the crafts revived and used as the brand story (Shang Xia - Chinese Fine Living). BMW's Efficient Dynamics technology was created to reduce harmful emissions and fuel consumption without sacrificing the comfort and pleasure of driving (Ivan et al., 2016).

One should not forget, however, that the important value of a luxury product is its uniqueness, due to its limited availability. However, such an approach is often possible through the use of raw materials the rarity of which is derived from limited natural resources. Examples may be leather goods made of exotic hides, rare animals, fur, or the most controversial - diamonds. The diamond industry, for example, has come under fire for benefiting from injustice along its supply chain. "Blood diamonds" or "conflict diamonds" are diamonds which have been sourced from war zones, where rebel groups often fund their campaigns through mining, frequently using children. Such situations have arisen in Angola, Liberia, Ivory Coast, Mozambique, Zimbabwe, the Democratic Republic of the Congo, and Congo-Brazzaville. International consumer and NGO pressure has caused diamond companies to scrutinise their supply chain, and has reduced the number of diamonds from conflict zones reaching the market (www.investopedia.com).

According to Kapferer (1998), sustainability is a part of the luxury business ethos:

(...) luxury is at its essence very close to sustainable preoccupations because it is nourished by rarity and beauty and thus has an interest in preserving them. The unique values of the luxury business - Uniqueness, Timelessness and Heritage, all overlap with the ideology of Sustainability. 
While many aspects of the perception of the luxury character of the product are in complete opposition to CSR principles, it is undeniable that luxury manufacturers must be involved in socially responsible activities. Especially as unlike smaller and less profitable companies, the luxury sector has tremendous financial capacity to operate effectively in this area - financial issues cannot be an excuse.

There are more and more organisations dealing exactly with the social responsibility of the luxury industry. This type of organisation is Positive Luxury, founded in 2011 by Diana Verde Nieto and Karen Hanton. Positive Luxury is a global award $=$ winning membership programme. Every brand featured in Positive Luxury must take care of its sourcing of raw materials, manufacturing, and marketing services. The members of Positive Luxury are for example: Alexander McQueen, Balenciaga, Berluti, Boucheron, Burberry, Chaumet, Dior, DKNY, Emilio Pucci, Fendi, Gucci, Louis Vuitton, etc.

Another example of the activities of luxury brands in the area of CSR is The GCC Brandmark. The founder of the Green Carpet Challenge (GCC) is Livia Firth, the Creative Director of Eco Age Limited. The GCC Brandmark is a guarantor of sustainable excellence and is awarded when the GCC social and ethical benchmark standards for a product or collection are met. Gucci is the brand awarded the GCC Brandmark as the first luxury brand, when it created, in partnership with Eco-Age, the world's first handbag collection made from zero-deforestation, certified Amazonian leather.

The evidence of the fact that the social responsibility of manufacturers of luxury goods is growing in importance, might be the emergence of the sector called "sustainable luxury". It is a growing market sector, which first emerged in 2004. The term essentially refers to luxury brands that produce high-end ready-to-wear and couture clothing using ethical and fair trade practices from start to finish.

\section{Research on the social responsibility of luxury - analysis of secondary sources}

Linking luxury brands to CSR activities, is still causing live discussions and it has many supporters and opponents. According to Torelli et al. (2012, p. 961), "differentiation based on the promotion of a CSR agenda might not be the best strategy for luxury brand". The authors also believe that communicating to clients that a luxury brand carries 
out CSR activities may suggest to consumers that "something is not right" and might negatively affect brand perception. (Torelli et al., 2012). The authors explain their findings by pointing to some abstract brand associated meanings (Park et al., 1991) that influence brand evaluation by activating specific motives (Chartrand et al., 2008).

Referring to the motives influencing perception of luxury brand, C. Jansen et al. (2014) point some conflicts between factors shaping perception of luxury and social responsibility of the luxury brand. One of the main objectives of CSR is a concern for welfare of others and the environment, which reflects self - transcendence values, while luxury is clearly linked to conspicuousness (Han et al., 2010), hedonism (Hagtvedt \& Patrick, 2009), and success (Mandel et al., 2006) - concepts that emphasize the consumers' own interests and well-being, or self-enhancement values. On this basis, the authors claim that the term "responsible luxury" may be treated as contradiction in terms. According to Torelli et al. (2012), Schwartz (1992), CSR - associated self - transcendence values conflict with luxury - associated self - enhancement values.

Although Schwartz points to areas of contradiction between luxury brands and CSR activities, the author also sees areas in which these issues are compatible. Among the significant features of luxury goods are: craftsmanship, art, creativity, high quality and respect to the material, timelessness, and the highest quality of products (Kapferer, 1998; Vigneron \& Johnson, 2004; Kapferer \& Bastien, 2009). According to Schwartz, under such assumptions, luxury could be associated with openness and conservation values, which are highly compatible with CSR - associated self - transcendence values (Schwartz, 2012; Janssen et al., 2014). According to these two opposing viewpoints, there are some factors which might accentuate perceptions that CSR and luxury are compatible, whereas others may trigger an opposite perception. This situation should inspire the luxury brands' managers to engage in responsible luxury, especially as the topic is becoming more and more popular. Considering the above described interdependencies and conflicts between CSR and luxury perception, it is important to note that luxury brand managers need a better understanding of the possibilities they can use to achieve high effectiveness in CSR and marketing strategies, if they are to take further steps toward more responsible business practices, but at the same time avoid the negative consequences of promoting responsible luxury (Torelli et al., 2012). 
An important aspect of the research on corporate social responsibility is the differences between consumers of luxury and commodity products occurring in this aspect. Taking into account the very specific motives of consumers of luxury goods, it can be assumed that their approach to CSR and ethical consumption will be completely different from the approach of other consumers (Nia \& Zaichhkowsky, 2000; Vigneron \& Johnson, 2004; Ward \& Chiari, 2008). However, it is acknowledged that this research area is still under-described and poorly analysed in the literature. Avies et al. investigated if consumers care about ethical luxury and if their behaviour differs significantly in comparison with the approach of consumers of commodity goods to ethical consumption. According to the research results of the above-mentioned authors:

- consumers are less likely to brand switch based on ethics due to the low priority of ethics in the purchasing decision,

- consumers are less inclined to identify or perceive high moral intensity to ethical issues in luxury products based on the "Fallacy of Clean-Luxury", the irregularity of purchase and reduced perception of peer pressure,

- the ethical-luxury brands would also face significant barriers (having less flexibility on price premiums, less active pursuit of information by ethical consumers, and lower perception of an ability to create social change).

At the same time, the results show that consumers do care about ethical-luxury, although it has not significantly affected their purchase decisions previously. Ethics is only a part of CSR, thus it should be mentioned that the above presented results of the studies do not show the problem of CSR in luxury business comprehensively.

The authors of the research conclude that at the present time ethical luxury is unlikely to keep pace with the growth of ethical commodities. The implication of this is that in years to come we may see the rise of some ethical luxuries, but due to resource, information search, and information salience it is unlikely that they will ever be as universally successful.

As already mentioned, the social responsibility of the luxury sector is not a popular research subject. Most of the literature tends to focus on non-luxury goods. In Poland, this topic is also not very well described. Polish scientists are more and more concerned about the luxury goods market, perception of luxury as well as segmentation and behaviour of consumers of luxury goods (Sikora, 2012; Bombol, 2012). The issue 
of social responsibility of the luxury business, however, is still little understood and examined. Interestingly, reports on the market of luxury goods in Poland and the behaviour of Polish consumers on this market also do not take into account CSR as a factor which could influence the purchasing decisions of Polish consumers. The KPMG research company conducts an annual research on the market and behaviour of consumers of luxury goods in Poland. One area of study is to assess the relevance of particular characteristics of luxury goods from the point of view of the buyers. It should be noted that in the studies conducted so far, there is no indication of CSR or ethical consumption, as important determinants of purchasing behaviour of Polish consumers. In Figure 3 , the results of the 2016 study are presented.

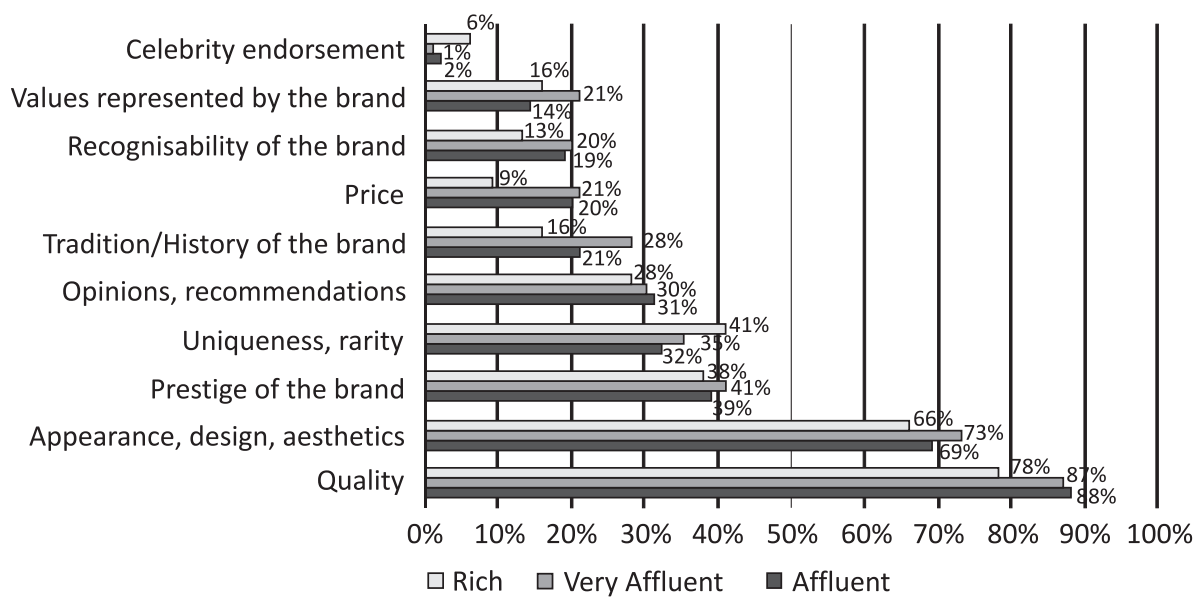

Figure 3. Factors that affluent and rich Poles consider in their decisions in purchasing luxury goods

Source: own work on the basis of: KPMG in Poland based on consumers research (2016), p. 21. The respondents could indicate a maximum of four important factors.

It should be noted that the characteristics pointed by Polish respondents may indicate the rationality of their purchasing decisions. The most important features of a luxury product are, according to them: quality, appearance, design, and aesthetics. What is important, however, is that the study did not include CSR or ethical behaviour as important factors influencing consumer decisions. The only areas in which these factors could be included are the values represented 
by the brand. However, without knowing the precise explanation of this factor, it is difficult to say clearly whether it contained CSR-associated values.

\section{CONCLUSIONS}

Responsible luxury is certainly a controversial statement. According to some researchers this notion even may appear as a contradiction in terms. The sceptics of necessity, and even the possibility of conducting socially responsible luxury business, believe that this type of market approach is not desirable from the consumer perspective. The assumptions of CSR stand in contradiction with such values of luxury as their social dimension. One of the problematic issues is, for example: how to reconcile conspicuous consumption with the image of a socially responsible company. On the one hand, luxury goods are meant to enable their consumers to stand out from the others, while on the other, they are supposed to be socially responsible. Such behaviour stands in contradiction to each other.

But there are some researchers and brand managers, who see in CSR both the opportunity and the responsibility. In their opinion, trends in ethical/socially responsible consumption that already exist in the mass market might be naturally transposed into the luxury dimension. Researchers of the phenomenon recognise the growing need to analyse this area and at the same time to make the luxury goods companies aware of the importance of CSR in their activities. The key question to answer is: whether the values of luxury products, considered relevant to their consumers, correspond to the basic principles of ethical/responsible consumption, and which stakeholder groups, really expect socially responsible behaviour from luxury brands.

The analysis of the literature, the studies of the importance of CSR for luxury goods' consumers, and examples of luxury brands' activities in this field, clearly indicate that although this dimension of brand value is not essential to its buyers, there are stakeholder groups who demand socially responsible behaviour from luxury brands. 


\section{REFERENCES}

Amatulli, C. et al. (2017). Sustainable Luxury Brands: Evidence from Research and Implications for Managers. London: Palgrave Macmillan.

Anderson, R.C. \& Hansen, E.N. (2004). Determining consumer preferences for ecolabelled forest products. Journal of Forestry, 102(4), 28-32.

Auger, P. et al. (2003). What will consumers pay for social product features? Journal of Business Ethics, 42(3), 281-304.

Bagwell, L.M. \& Bernheim, B.D. (1996). Veblen effects in a theory of conspicous consumption. The American Economic Review, Jun 1996, ABI/INFORM Global, 349-373.

Barnier, V. de, Rodina, I. \& Valette-Florence, P. (2006). Which luxury perceptions affect most consumer purchase behavior? A cross-cultural exploratory study in France, the United Kingdom and Russia. Working Paper. Grenoble: University Pierre Mendes France, http://citeseerx.ist.psu.edu/viewdoc/download?doi=10.1.1.628.4670\&rep=rep1\&type=pdf (accessed: 22th May 2018).

Bendell, J. \& Kleanthous, A. (2007). Deeper Luxury, www.wwf.org.uk/deeperluxury (accessed: 22nd May 2018).

Berry, C.J. (1994). The Idea of Luxury: A Conceptual and Historical Investigation. Cambridge: Cambridge University Press.

Berthon, P. et al. (2009). Aesthetics and ephemerality: Observing and preserving the luxury brand. California Management Review, 55(1), 45-66.

Bjørner, T.B., Hansen, L.G. \& Russell, C.S. (2004). Environmental labelling and consumers' choice. An empirical analysis of the effect of the Nordic Swan. Journal of Environmental Economics and Management, 47(3), 411-424.

Bombol, M. (red.) (2012). Badania polskiej klasy wyższej. Problemy, diagnozy, dylematy. Warszawa: Oficyna Wydawnicza SGH.

Bourdieu, P. (1984) Distinction: A Social Critique of the Judgement of Taste. Cambridge: Harvard University Press.

Bowen, H.R. (1953). Social Responsibilities of the Businessman. New York: Harper and Row.

Caroll A.B. \& Shabana, K.M. (2016). The business case for corporate social responsibility: A review of concepts, research and practice. International Journal of Management Reviews, 12(1), 85-105.

Carroll, A.B. (1991). The pyramid of corporate social responsibility: Toward the moral management of organizational stakeholders. Business Horizons, 34, 39-48.

Carroll, A.B. (1999). Corporate social responsibility: Evolution of a definitional construction. Business and Society, 38(3), 268- 295. 
Chartrand, T.L. et al. (2008). Nonconscious goals and consumer choice. Journal of Consumer Research, 35(2), 189-201.

Chevalier, M. \& Mazzalovo, G. (2008). Luxury Brand Management. A World of Privilege. Singapore: John Wiley \& Sons.

Cornell, A. (2002). Cult of luxury: The new opiate of the masses. Australian Financial Review, 27th April.

Czubała, A. (2011). Rola konsumentów w realizacji koncepcji społecznej odpowiedzialności przedsiębiorstw. Konsumpcja i Rozwój, 1, 58-66.

Dahlsrud, A. (2005). A comparative study of CSR-strategies in the oil and gas industry. Paper presented at Navigating Globalization: Stability, Fluidity, and Friction, Trondheim.

Davies, I.A., Lee, Z. \& Ahonkhai, I. (2012). Do consumer care about ethical luxury? Journal of Business Ethics, 106(1), 37-51.

Dryl, T. (2014). Zaufanie konsumenta do marki produktu na rynku konsumpcyjnym. Marketing i Rynek, 8, 1044-1051.

Dryl, W. \& Gil, L. (2016). Stosunek młodych polskich konsumentów do produktów luksusowych. Handel Wewnętrzny, 2(361), 101-113.

Dubois, B. \& Laurent, G. (1994). Attitudes toward the concept of luxury: An exploratory analysis. Asia-Pacific Advances in Consumer Research, 1(2), 273-278.

Dubois, B., Laurent, G. \& Czellar, S. (2001). Consumer Rapport to Luxury: Analyzing Complex and Ambivalent Attitudes. HEC Research Papers Series No. 736.

Engle, R.L. (2006). Corporate Social Responsibility in Host Countries: A Perspective from A merican Managers. Corporate Social Responsibility and Environmental Management, 14, 16-27.

Gardyn, R. (2002). Oh, the good life. American Demographics, 24(10), 31-35.

Glan, J.I. (2006). Corporate social responsibility and strategic management. Journal of Management Studies, 43(7), 1629-1641.

Hagtvedt, H. \& Patrick, V.M. (2009). The broad embrace of luxury: Hedonic potential as a driver of brand extendibility. Journal of Consumer Psychology, 19(4), 608-618.

Han, Y.J., Nunes, J.C. \& Drèze, X. (2010). Signaling status with luxury goods: The role of brand prominence. Journal of Marketing, 74(4), 15-30.

Harrison, R., Newholm, T. \& Shaw, D. (2005). The Ethical Consumer. London: Sage Publications.

Heine, K. \& Sikora, T. (2012). Pojęcie marki luksusowej, http://conceptofluxurybrands. com/content/20121107_Heine_The-Concept-of-Luxury-Brands.pdf (accessed: 10th Oct 2017).

Ivan, C.-M. et al. (2016). Long-Term Sustainability in Luxury. Where Else, Handbook of Sustainable Luxury Textile and Fashion. Singapore: Springer Science+Business Media. 
Janssen, C. et al. (2014). The catch-22 of responsible luxury: Effects of luxury product characteristics on consumers' perception of fit with corporate social responsibility. Journal of Business Ethics, 119(1), 45-57.

Kapferer, J.-N. \& Bastien, V. (2009). The specificity of luxury management: Turning marketing upside down. Journal of Brand Management, 16(5/6), $311-322$.

Kapferer, J.-N. (1997). Managing luxury brands. Journal of Brand Management, 4(4), 251-260.

Kapferer, J.-N. (1998). Why are we seduced by luxury brands? Journal of Brand Management, 6(1), 44-49.

Kapferer, J.-N. (2008). The New Strategic Brand Management. London: Kogan Page.

Keller, K.L. (2009). Managing the growth tradeoff: Challanges and opportunities in luxury branding. Journal of Brand Management, 16(5/6), 290-301.

Kemp, S. (1998). Perceiving luxury and necessity. Journal of Economic Psychology, 19(5), 591-606.

Leibenstein, H. (1950). Bandwagon, snob, and veblen effects in the theory of consumers' demand. The Quarterly Journal of Economics (May), 183-207.

Loureiro, M.L. \& Lotade, J. (2005). Do fair trade and eco-labelling in coffee wake up the consumer conscience? Ecological Economics, 53(1), 129-138.

Mandel, N., Petrova, P.K. \& Cialdini, R.B. (2006). Images of success and the preference for luxury brands. Journal of Consumer Psychology, 16(1), 57-69.

Mason, R.S. (1992). Modeling the demand for status goods. Association for Consumer Research [special vol.], 88-95.

McGoldrick, P.J. \& Freestone, O.M. (2008). Ethical product premiums: Antecedents and extent of consumers' willingness to pay. International Review of Retail, Distribution and Consumer Research, 18(2), 185-201.

McKinsey (1990). The Luxury Industry: An Asset for France. Paris: McKinsey.

Mortelmans, D. (2005). Sign values in processes of distinction: The concept of luxury. Semiotica, 157, 497-520.

Nia, A. \& Zaichkowsky, J.L. (2000). Do counterfeits devalue the ownership of luxury brands? Journal of Product and Brand Management, 9(7), 485-497.

Nueno, J.L. \& Quelch, J.A. (1998). The mass marketing of luxury. Business Horizons, 41(6), 61-68.

Park, C.W., Milberg, S.J. \& Lawson, R. (1991). Evaluation of brand extensions: The role of product level similarity and brand concept consistency. Journal of Consumer Research, 18(2), 185-193.

Pelsmacker, P. de, Driesen, L. \& Rayp, G. (2005). Do consumers care about ethics? Willingness to pay for fair trade coffee. Journal of Consumer Affairs, 39(2), 363-385. 
Phau, I. \& Prendergast, G. (2000). Consuming luxury brands: The relevance of the "rarity principle". Journal of Brand Management, 8, 122-138.

Raczkowski, K., Sułkowski, Ł. \& Fijałkowska, J. (2016). Comparative critical review of Corporate Social Responsibility Business Management Models. International Journal of Contemporary Management, 15, 123-150.

Rojek-Nowosielska, M. (2015). Desired versus existing CSR practises: A research perspective. International Journal of Contemporary Management, 14(4), 23-44.

Roux, E. \& Floch, J.M. (1996). Gerer l'ingerable: La contradiction interne de toute maison de luxe. Decisions Marketing, 15-23.

Ruiz, D.M., Barroso, C. \& Armario, E.M. (2007). Explaining market heterogeneity in terms of value perceptions. The Service Industries Journal, 27(8), 1087-1110.

Schwartz, S.H. (1992). Universals in the content and structure of values: Theoretical advances and empirical tests in 20 countries. Advances in Experimental Social Psychology, 25, 1-65.

Schwartz, S.H. (2012). An overview of the Schwartz theory of basic values. Online Readings in Psychology and Culture, 2(1).

Seifert, B., Morris, S.A. \& Bartkus, B.R. (2003). Comparing big givers and small givers: Financial correlates of corporate philanthropy. Journal of Business Ethics, 45, 195-211.

Sikora, T. (2012). Zachowania nabywców produktów luksusowych. Warszawa: Oficyna Wydawnicza SGH.

Smith, J.B. \& Colgate, M. (2007). Customer value creation: A practical framework. Journal of Marketing Theory and Practice, 15(1), 7-23.

Sweeney, J.C. \& Soutar, G.N. (2001). Consumer-perceived value: The development of a multiple item scale. Journal of Retailing, 77(2), 203-220.

Tokarski, K. (1999). Give and thou shall receive. Public Relations Quarterly, 44(2), 34-40.

Torelli, C.J., Monga, A.S.B. \& Kaikati, A.M. (2012). Doing poorly by doing good: Corporate social responsibility and brand concepts. Journal of Consumer Research, 38(5), 948-963.

Tynan, C., Mckechine, S. \& Chhuon, C. (2010). Co-creating value for luxury brands. Journal of Business Research, 63(11), 1156-1163.

Van der Veen, M. (2003). When is food a luxury? World Archaeology, 34(3), 406-407.

Vickers, J.S. \& Renand, F. (2003). The marketing of luxury goods: An exploratory study - Three conceptual dimensions. The Marketing Review, 3(4), 459-478.

Vigneron, F. \& Johnson, L.W. (1999). A review and a conceptual framework of prestige-seeking consumer behavior. Academy of Marketing Science Review, $3(1), 2-8$. 
Vigneron, F. \& Johnson, L.W. (2004). Measuring perceptions of brand luxury. Journal of Brand Management, 11(6), 484-506.

Wang, Y., Sun, S. \& Song, Y. (2010). Motivation form luxury consumption: Evidence from a metropolitan city in China. Research in Consumer Behavior, 12, 161-181.

Ward, D. \& Chiari, C. (2008). Keeping Luxury Inaccessible, www.mpra.ub.unimuenchen.de/11373/1/MPRA_paper_11373.pdf (accessed: 22th May 2018).

Wartick, S.L. \& Cochran, P.L. (1985). The evolution of the corporate social performance model. Academy of Management Review, 10, 758-769.

Wiedmann, K.-P., Hennigs, N. \& Siebels, A. (2009). Value-based segmentation of luxury consumption behavior. Psychology \& Marketing, 26, 625-651.

Woodall, T. (2003). Conceptualising 'value for the customer': An attributional, structural and dispositional analysis. Academy of Marketing Science Review, 12. 